\title{
BERTRAND RUSSELL
}

Tekst został przetłumaczony na postawie: B. Russell, Am I An Atheist Or An Agnostic? A Plea For Tolerance In The Face Of New Dogmas, w: tenże, The collected papers of Bertrand Russell, t. 11. Last philosophical testament 1943-68, Routledge, London-New York 1997, s. 89-92. Serdecznie dziękujemy wydawnictwu Routledge oraz The Bertrand Russell Peace Foundation (http://www.russfound.org/) za zgodę na publikację tłumaczenia.

\section{Czy jestem ateistą, czy agnostykiem? Obrona tolerancji przeciw nowym dogmatom.}

(fragmenty wykładu)

ój ojciec chciał, abym został wychowany na racjonalistę. Choć był on w pełnym tego słowa znaczeniu racjonalistą - takim samym, jakim dzisiaj jestem ja - to zmarł, gdy miałem trzy lata i sąd zdecydował, że będę musiał odebrać chrześcijańskie wychowanie. Myślę, iż ów sąd mógł od tego czasu pożałować swojej decyzji - nie wydaje się bowiem, aby przyniosła ona tyle dobrego, ile się po niej spodziewano.

Moim zdaniem zaprzestanie chrześcijańskiej edukacji poskutkowałoby tym, iż nie wychowano by już więcej racjonalistów. Racjonaliści wyrastają bowiem głównie w reakcji na system edukacji, który uważa za słuszne, aby ojciec decydował o tym, czy jego syn ma wyrosnąć na np. muggletonianina czy na innego rodzaju nonsensowną postać, ale pod żadnym warunkiem nie chce dopuścić, aby wyrósł na człowieka myślącego racjonalnie. Gdy byłem młody, racjonalne myślenie było bowiem uważane za nielegalne i niebezpieczne.

\section{Księża i grzech}

Od kiedy stałem się racjonalistą, odkryłem, że na świecie ciągle istnieje znaczny obszar, na którym pogląd racjonalistyczny ma realne znaczenie -

\footnotetext{
*Pełen tekst tłumaczenia dostępny jest w drukowanej wersji pisma.
} 
nie tylko w dziedzinie np. geologii, ale we wszelakich rodzajach spraw praktycznych, takich jak rozwody, kontrola urodzeń czy sztuczne zapłodnienie, o których księża mówią, iż są śmiertelnie grzeszne, tylko dlatego, że traktuje o nich jakiś passus w Biblii. Działania te nie są złe z powodu cierpień, jakich komuś przysparzają - to nie jest racją ich grzeszności. Tak długo, jak Parlament może twierdzić, iż jakiś czyn powinien być zakazany z powodu istnienia w Biblii tekstu mówiącego o jego grzeszności, tak dalece istnieje wielka potrzeba racjonalizmu w sferze praktycznej.

Jak powszechnie wiadomo, popadłem $\mathrm{w}$ Stanach Zjednoczonych $\mathrm{w}$ wielkie tarapaty tylko dlatego, że $\mathrm{w}$ pewnych praktycznych sprawach uważałem, iż etyczne rady wyłożone w Biblii nie są wiążące i że w niektórych sytuacjach można działać inaczej, niż nakazuje to Biblia. Na tej podstawie sąd amerykański uznał, że nie powinienem wykładać na jakimkolwiek uniwersytecie w Stanach Zjednoczonych - mam więc pewną realną podstawę, aby preferować racjonalizm względem innych poglądów. (...) 